\title{
EFEK STERILISASI DAN KOMPOSISI MEDIA PRODUKSI INOKULAN FUNGI MIKORIZA ARBUSKULA TERHADAP KOLONISASI AKAR, PANJANG AKAR DAN BOBOT KERING AKAR SORGUM
}

\section{EFFECT OF STERILIZATION AND MEDIUM COMPOSITION FOR MYCORRHIZAL FUNGI ON ROOT COLONISATION, LENGTH AND WEIGHT OF SORGHUM ROOT}

\author{
Tarra Martiani Dewi, Anne Nurbaity, Pudjawati Suryatmana, Emma Trinurani Sofyan \\ Departemen Ilmu Tanah dan Sumberdaya Lahan \\ Fakultas Pertanian Universitas Padjadjaran \\ Jl. Raya Bandung-Sumedang Km. 21 Jatinangor 45363 \\ Korespondensi : a.nurbaity@unpad.ac.id
}

Diterima 26 Februari 2017 / Disetujui 29 Juli 2017

\begin{abstract}
ABSTRAK
Pengujian kualitas inokulan mikoriza yang berkualitas antara lain dapat dilakukan melalui optimasi metode sterilisasi dan komposisi media. Penelitian yang bertujuan untuk mengetahui pengaruh sterilisasi dan komposisi media terhadap derajat infeksi akar, panjang akar, dan bobot kering akar sorgum telah dilakukan di rumah kaca. Percobaan menggunakan Rancangan Acak Kelompok pola faktorial terdiri atas perlakuan faktor pertama berupa sterilisasi media yang terdiri atas empat taraf, yaitu: tanpa sterilisasi (kontrol); autoklaf; $\mathrm{NaOCl} 10 \%$; dan iradiasi gamma Co-60, serta faktor kedua adalah komposisi media tanam yang terdiri atas tiga taraf yaitu: $100 \%$ zeolit; $75 \%$ zeolit $+25 \%$ arang sekam; dan $50 \%$ zeolit $+50 \%$ arang sekam. Hasil penelitian menunjukkan bahwa tidak terdapat interaksi antara perlakuan sterilisasi dan komposisi media tanam terhadap peningkatan kolonisasi akar, panjang akar, dan bobot akar sorgum. Teknik sterilisasi media berpengaruh terhadap kolonisasi akar, panjang akar dan bobot akar sorgum. Teknik sterilisasi dengan autoklaf dan iradiasi tidak berbeda nyata dengan kontrol dalam meningkatkan kolonisasi akar, panjang akar dan bobot akar sorgum, namun iradiasi Gamma cenderung memperlihatkan hasil terbaik. Perlakuan komposisi media zeolit dan arang sekam secara umum tidak memberikan perbedaan yang nyata, sehingga produksi inokulan FMA dapat menggunakan berbagai komposisi sesuai dengan ketersediaan bahannya.
\end{abstract}

Kata kunci : arang sekam, mikoriza arbuskula, sorgum, sterilisasi iradiasi, zeolit

\begin{abstract}
Quality of biofertilizer such as arbuscular myorrhizal fungi could be improved through the selection of appropriate sterilization and composition of the medium. The objective of the experiment was to determine the effect of sterilization and carrier composition on root colonisation, root length and weight of sorghum root. A green house experiment was conducted in randomized block design. The factors were: 1 . methods of sterilization (ie. control; autoclave; $\mathrm{NaOCl} 10 \%$; Co-60 gamma irradiation), and 2. composition of the carrier of mycorrhiza ( $100 \%$ zeolite; $75 \%$ zeolite $+25 \%$ rice charcoal; $50 \%$ zeolite $+50 \%$ rice charcoal).
\end{abstract}


Results showed that there was no interaction effect of sterilization and composition of carrier on root colonisation, root length and weight of sorghum root. However, different technique of sterilisation gave differences on root colonisation, root length and weight of sorghum root. Sterilization using $\mathrm{NaOCl} 10 \%$ was not recommended. Gamma Co-60 irradiation sterilization did not have difference with control and autoclave, however there was tendency that irradiation technique gave better results to all parameters measured.

Key words: arbuscular mycorrhiza, irradiation sterilisation, rice husk, sorghum, zeolite

\section{PENDAHULUAN}

Berbagai kerugian akibat kegiatan pertanian intensif dengan input tinggi menyebabkan menurunnya kualitas kesuburan tanah dan degradasi lahan, sehingga pengelolaan lahan pertanian saat ini harus lebih berorientasi kepada pertanian yang berkelanjutan. Upaya perbaikan yang dapat ditempuh untuk mengatasi masalah tersebut yaitu melalui introduksi teknologi yang bersifat ramah lingkungan dan ekonomis. Salah satunya adalah dengan memanfaatkan potensi sumberdaya hayati setempat, melalui pengembangan mikroba tanah yang dapat membantu meningkatkan kualitas tanah yang berasal dari golongan fungi dan bakteri sebagai pupuk hayati.

Pupuk hayati merupakan inokulan berbahan aktif organisme hidup yang berfungsi untuk menambah hara tertentu atau memfasilitasi tersedianya hara dalam tanah bagi tanaman (Simanungkalit, 2006). Salah satu mikroorganisme yang dimanfaatkan sebagai pupuk hayati yang telah diketahui mampu meningkatkan produktivitas pertumbuhan tanaman yaitu Fungi Mikoriza Arbuskula (FMA). Menurut Rao (1994) FMA dapat membantu penyediaan hara, terutama fosfat bagi tanaman melalui kolonisasi akar tanpa menimbulkan nekrosis seperti halnya terjadi pada infeksi jamur pathogen. Jenis FMA yang umum dijumpai adalah Glomus, Gigaspora, Acaulospora dan Scutellospora (Brundrett et al., 1996). Pemilihan isolat FMA yang benar-benar kompatibel dengan tanaman yang dibudidayakan perlu dilakukan karena setiap jenis FMA memiliki kemampuan yang berbedabeda dalam membantu meningkatkan pertumbuhan tanaman (Tian et al., 2004).

Salah satu hambatan belum meluasnya penggunaan teknologi FMA di masyarakat petani Indonesia adalah masih terbatasnya ketersediaan inokulan FMA yang diproduksi dalam skala besar secara komersial (Nurbaity et al., 2009). Ketersediaan inokulan FMA harus diikuti dengan kualitas inokulan yang diukur berdasarkan jumlah spora, persen infeksi akar, panjang akar, serta bobot akar tanaman inang, untuk itu faktor penting dalam proses produksi FMA, antara lain tanaman inang, media tanam, dan nutrisi (ljdo et al., 2010). Sterilisasi media tumbuh dalam produksi FMA bertujuan untuk meminimalkan gangguan oleh mikroorganisme yang tidak dikehendaki (kontaminan), agar tidak mengalami kerusakan yang dapat mempengaruhi kualitas inokulan. Sterilisasi media dapat dilakukan dengan tiga cara yaitu secara mekanik, fisik dan kimiawi. Pada penelitian ini teknik sterilisasi media tumbuh dalam produksi FMA dilakukan secara fisik dan mekanik yaitu melalui teknik sterilisasi media menggunakan Iradiasi Sinar Gamma Co-60, autoklaf, 
penambahan larutan $\mathrm{NaOCl} 10 \%$, dan pencucian media dengan air kran.

Sinar Gamma termasuk gelombang elektromagnetik yang diperoleh dari peluruhan zat radioaktif yang dipancarkan dari atom dengan kecepatan tinggi karena adanya kelebihan energi. Radioaktivitasnya tidak terpengaruh oleh suhu, kelembaban, tekanan dan lain-lain tetapi terpengaruhi oleh keadaan inti-inti isotopnya. Autoklaf merupakan pressure cooker yang sangat efektif me-matikan mikroba karena pada suhu $121^{\circ} \mathrm{C}$ dapat melepaskan 686 kalori g $^{-1}$ uap air. Sterilisasi media autoklaf dilakukan dengan cara memanfaatkan uap air panas. Mekanisme kerusakan oleh panas ini ditandai dengan rusaknya produksi rantaitunggal DNA akibat tekanan tinggi yang menyebabkan penetrasi uap air ke dalam sel-sel mikroba menjadi optimal sehingga langsung mematikan mikroba.

Sodium hypoklorit $(\mathrm{NaOCl})$ seringkali digunakan sebagai bahan pemutih atau desinfektan. Senyawa ini sangat efektif membunuh bakteri dan virus. Senyawa $\mathrm{NaOCl}$ mampu membersihkan mikroorganisme yang terbawa dalam bahan tanaman, menghilangkan pertikel-partikel tanah, debu dan lain-lain (Santoso dan Nursandi, 2003).

Komposisi media tumbuh dalam produksi FMA dapat berupa tanah, pasir, expanded clay (agregat liat), gambut dan zeolit (Simanungkalit, 2003). Bahan media (carrier) dapat diperoleh dalam jumlah besar, ringan, bersifat porus, homogen dan murah (Prematuri dan Faiqoh, 1999). Pada pene-litian ini komposisi media tumbuh produksi FMA menggunakkan zeolit dan arang sekam. Zeolit baik digunakan sebagai media tanam karena bersifat stabil dan tidak mudah berubah atau rusak karena siraman air (Bertham, 2003). Zeolit merupakan mineral yang mampu memperbaiki produktivitas tanah dan tanaman karena bersifat basa, sehingga dapat menetralkan tanah yang bersifat asam, mengurangi daya fiksasi P oleh koloid tanah dan meningkatkan KTK serta aktivitas mikroorganisme dalam tanah (Departemen Pertanian, 2001). Penggunaan arang sekam sebagai media tumbuh inokulan FMA masih belum banyak dilakukan, padahal sumber bahan media arang sekam padi dapat diperoleh dalam jumlah besar, ringan, bersifat porus, homogen dan murah (Prematuri dan Faiqoh, 1999). Beberapa hasil penelitian diketahui bahwa bahan organik mendukung perkembangan propagul FMA (St. John et al., 1983; Nurbaity et al., 2009).

Tanaman inang yang biasa digunakan untuk perbanyakan FMA adalah sorgum karena sistem perakarannya yang baik untuk pembentukan mikoriza (Gunawan, 1999; Prematuri dan Faiqoh, 1999). Sorgum toleran terhadap kekeringan, dapat tumbuh hampir di setiap jenis tanah, serta membentuk akar-akar sekunder dua kali lebih banyak dibandingkan dengan tanaman lain, berakar dalam dan fibrous sehingga lebih efektif dalam menyerap hara dan air (Departemen Pertanian, 1990).

Berdasarkan uraian di atas telah diketahui manfaat dari FMA, namun informasi tentang metode sterilisasi dan komposisi media terbaik sebagai alternatif dalam proses produksi inokulan FMA masih terbatas. Dengan demikian pada penelitian ini efek sterilisasi dan komposisi media dengan pemanfaatan FMA diharapkan dapat ber-pengaruh terhadap peningkatan persentase infeksi akar, panjang akar, serta bobot akar tanaman sorgum untuk menghasilkan inokulan FMA yang unggul dan berkualitas. 


\section{METODE PENELITIAN}

Percobaan ini dilaksanakan di Rumah Kaca Kebun Percobaan Fakultas Pertanian Universitas Padjadjaran, Laboratorium Biologi Tanah Departemen Ilmu Tanah Fakultas Pertanian, serta Pusat Aplikasi Tenaga Nuklir Batan untuk perlakuan iradiasi sinar gamma. Percobaan menggunakan Rancangan Acak Kelompok (RAK) pola faktorial yang terdiri atas dua faktor dengan tiga ulangan. Faktor pertama adalah sterilisasi media (S) yang terdiri atas : kontrol (s0), autoklaf $121^{\circ} \mathrm{C}$ selama 30 menit (s1), direndam $\mathrm{NaOCl} 10 \%$ selama 5 menit (s2), dan iradiasi gamma Co-60 (s3). Faktor kedua adalah komposisi media tumbuh $(\mathrm{K})$ yang terdiri atas : $100 \%$ zeolit (kontrol, k0), 75\% zeolit + 25\% Arang sekam $(3: 1 \mathrm{v} / \mathrm{v})(\mathrm{k} 1)$, dan $50 \%$ zeolit $+50 \%$ arang sekam (1:1 v/v) (k2).

Bahan penelitian ini terdiri atas media zeolit, arang sekam padi yang ditimbang sesuai dengan perlakuan untuk dimasukkan ke dalam pot, benih sorgum $0,25 \mathrm{~kg}$ varietas Grain Sorgum B-100 yang direndam dalam larutan klorok 2\% selama 10 menit hingga terkelupas kulit arinya dan dibilas hingga bersih dengan air, pupuk NPK Hyponex merah (25-5-20), $\mathrm{KOH} \mathrm{10 \% ,} \mathrm{HCl} 1 \%$, larutan asam fuchsin, $\mathrm{NaOCl} 10 \%$ yang digunakan untuk sterilisasi media, air, inokulan FMA campuran yang terdiri atas Glomus sp., Acaulospora sp., dan Gigaspora decipien dengan kepadatan spora 300 spora per 50 g. Alat yang digunakan pada percobaan ini terdiri atas: pot plastik kapasitas $750 \mathrm{~g}$, autoklaf, mikroskop binokuler dan peralatan laboratorium lainnya.

Inokulasi FMA diaplikasikan dengan cara memasukan $70 \mathrm{~g}$ per pot inokulan FMA ke dalam media tanam di pot sesuai perlakuan, lalu diinkubasikan selama 1 minggu. Selama menunggu proses inkubasi dilakukan proses pengecambahan benih sorgum menggunakan baki kecambah bermedia zeolit.

Setiap pot ditanami 2 bibit tanaman sorgum. Pemupukan dilakukan dengan memberikan larutan Hyponex merah (25-5-

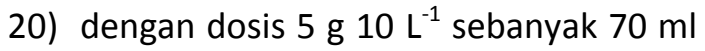
per pot dan diulang setiap dua kali seminggu selama 2,5 bulan (Prematuri dan Faiqoh, 1999). Pemupukan dan penyiraman dihentikan dan dilakukan pengeringan (stressing) selama dua minggu sebelum dilakukan pemanenan untuk merangsang pertumbuhan spora. Pengamatan kolonisasi akar diamati pada 6 dan 10 minggu setelah tanam (MST), pengamatan panjang akar dan bobot akar kering sorgum diamati 10 MST. Pemanenan dilakukan pada fase vegetatif akhir yaitu pada umur tanaman 10 MST. Panen dilakukan dengan cara membongkar tanaman inang lalu mencampur dan mengaduk media tanam, kemudian memotong akar tanaman sekitar $1 \mathrm{~cm}$ menggunakan gunting, lalu men-campurkan potongan akar tersebut dengan media pembawa zeolit dan arang sekam kemudian dikemas dalam kantong plastik. Setelah itu, dilakukan pengujian kualitas inokulan FMA dengan cara menganalisis kolonisasi akar (metode Brundrett et al., 1986), panjang akar, dan bobot akar kering sorgum di Laboratorium Biologi Tanah. Analisis statistik menggunakan software SPSS 12 dan uji lanjut menggunakan uji Duncan.

\section{HASIL DAN PEMBAHASAN}

\section{Persentase Kolonisasi Akar}

Hasil analisis menunjukkan bahwa tidak terjadi interaksi antara sterilisasi dan komposisi media terhadap peningkatan 
persentase kolonisasi akar yang diukur pada 10 minggu setelah tanam, namun, terdapat pengaruh mandiri sterilisasi media terhadap persentase kolonisasi akar (Tabel 1).

Tabel 1. Pengaruh Jenis Sterilisasi Media dan Komposisi Media terhadap Kolonisasi Akar

\begin{tabular}{lc}
\hline \multicolumn{1}{c}{ Perlakuan } & $\begin{array}{c}\text { Kolonisasi } \\
\text { Akar } \\
10 \mathrm{MST}\end{array}$ \\
\hline $\begin{array}{c}\text { Sterilisasi (S) } \\
\text { kontrol } \\
\text { autoklaf }\end{array}$ & $--\%--$ \\
NaOCl 10\% & $38,05 \mathrm{~b}$ \\
Iradiasi Gamma Co-60 & $38,05 \mathrm{~b}$ \\
\hline Komposisi Media (K) & $30,43 \mathrm{a}$ \\
zeolit 100\% & $46,06 \mathrm{~b}$ \\
zeolit 75\% + arang sekam 25\% & 37,97 \\
zeolit 50\% + arang sekam 50\% & 38,69 \\
\hline Keterangan : Nilai rata-rata yang diikuti huruf \\
yang sama tidak berbeda nyata \\
menurut Uji Lanjut Jarak \\
Berganda Duncan pada taraf 5\%.
\end{tabular}

Berdasarkan hasil analisis pada Tabel 1 terlihat bahwa perlakuan sterilisasi dan komposisi media produksi FMA menunjukkan adanya pengaruh mandiri dari efek sterilisasi. Hasil analisis persentase kolonisasi akar menunjukkan bahwa perlakuan sterilisasi kontrol dan menggunakan autoklaf menghasilkan persentase kolonisasi akar masing-masing sebanyak $38,05 \%$, sedangkan sterilisasi menggunakan iradiasi gamma Co-60 menghasilkan persentase kolonisasi akar sebanyak 46,06\%. Ketiga perlakuan tersebut berbeda nyata dengan perlakuan sterilisasi menggunakan $\mathrm{NaOCl} 10 \%$ yang menghasilkan persentase kolonisasi akar yang tergolong kategori sedang, yaitu sebesar 30,43\%. Penelitian Nurrobifahmi et al. (2017) menunjukkan bahwa sterilisasi autoklaf, radiasi sinar gamma mampu mensterilkan bahan pembawa di zeolit. Pada penyimpanan 1 bulan pasca sterilisasi menggunakan autoklaf pada zeolit viabilitas spora G. margarita tertinggi sebesar $46,95 \%$, sedangkan pada penyimpa-nan 3 bulan pasca sterilisasi pada radiasi dosis $10 \mathrm{kGy}$ pada zeolit viabilitas spora G. margarita tertinggi sebesar 45,81\%.

Perlakuan sterilisasi dengan $\mathrm{NaOCl} 10 \%$ berpengaruh nyata terhadap penurunan persentase kolonisasi akar, sehingga menghasilkan persentase kolonisasi akar paling rendah dibandingkan dengan perlakuan media lainnya, diduga oleh adanya unsur toksik seperti chloride $(\mathrm{Cl})$. Unsur $\mathrm{Cl}$ dapat menyebabkan proses kolonisasi dan perkembangan hifa menjadi terhambat (Juniper dan Abbott, 2004).

Perlakuan berbagai komposisi media idak berpengaruh nyata terhadap persentase kolonisasi akar, hal ini menunjukkan bahwa masing-masing komposisi media zeolit dan arang sekam memiliki kemampuan yang sama dalam meningkatkan persentase kolonisasi akar. Hasil penelitian Prafithriasari dan Nurbaity (2010) menunjukkan bahwa penggunaan media arang sekam dan zeolit dengan perbandingan 1:3 merupakan komposisi yang baik untuk produksi FMA, walaupun dari hasil penelitian ini komposisi tersebut memberi respon yang tidak berbeda dengan komposisi lainnya.

\section{Bobot Kering dan Panjang Akar}

Penghitungan bobot kering akar sorgum dilakukan pada saat tanaman berumur 10 MST, dimana bagian tanaman yang dianalisis ialah akar yang telah mengalami pengeringan akibat perlakuan stressing. Hasil analisis ragam menunjukkan bahwa tidak terjadi interaksi antara sterilisasi dan komposisi media terhadap bobot akar sorgum, namun terjadi pengaruh mandiri 
sterilisasi terhadap bobot akar sorgum (Tabel 2).

Tabel 2. Pengaruh Teknik Sterilisasi dan Komposisi Media terhadap Bobot Kering Akar Sorgum

\begin{tabular}{|c|c|}
\hline Perlakuan & $\begin{array}{l}\text { Bobot Kering } \\
\text { Akar Sorgum }\end{array}$ \\
\hline \multicolumn{2}{|l|}{ Sterilisasi (S) } \\
\hline kontrol & $6,07 \mathrm{~b}$ \\
\hline autoklaf & $6,90 \mathrm{~b}$ \\
\hline $\mathrm{NaOCl} 10 \%$ & $4,17 \mathrm{a}$ \\
\hline Iradiasi Gamma Co-60 & $7,07 \mathrm{~b}$ \\
\hline \multicolumn{2}{|l|}{ Komposisi Media (K) } \\
\hline zeolit $100 \%$ & $5,87 a$ \\
\hline $\begin{array}{l}\text { zeolit } 75 \% \text { + arang } \\
\text { sekam } 25 \%\end{array}$ & 6,05 a \\
\hline $\begin{array}{l}\text { zeolit } 50 \% \text { + arang } \\
\text { sekam } 50 \%\end{array}$ & 6,04 a \\
\hline \multicolumn{2}{|c|}{$\begin{array}{r}\text { Keterangan : } \\
\text { Nilai rata-rata yang diikuti huruf } \\
\text { yang sama tidak berbeda nyata } \\
\text { menurut } \quad \text { ji Lanjut Jarak }\end{array}$} \\
\hline
\end{tabular}

Data pada Tabel 2 menunjukkan adanya pengaruh mandiri dari efek sterilisasi. Perlakuan kontrol dan sterilisasi menggunakan autoklaf menghasilkan bobot akar masing-masing sebanyak $6,90 \mathrm{~g}$ per pot dan 6,07 g per pot, dan tidak berbeda nyata dengan sterilisasi menggunakan iradiasi gamma Co-60 menghasilkan bobot akar 7,07 g per pot, namun berbeda nyata dengan perlakuan sterilisasi $\mathrm{NaOCl} 10 \%$ menghasilkan bobot akar 4,17 g per pot. Perlakuan sterilisasi media dengan pemberian $\mathrm{NaOCl} 10 \%$ menghasilkan bobot akar paling rendah diduga oleh adanya unsur toksik yang terkandung dalam media yang menyebabkan proses kolonisasi dan perkembangan hifa menjadi terhambat, yang menyebabkan ketersediaan hara rendah. Smith dan Read (1997) menyatakan bahwa adanya kolonisasi mikoriza yang meningkat menyebabkan luas dan volume permukaan akar menjadi lebih besar, sehingga bobot akar yang dihasilkan lebih tinggi.

Pada parameter panjang akar sorgum, hasil analisis ragam menunjukkan tidak terjadinya interaksi antara sterilisasi dan komposisi media terhadap panjang akar sorgum, namun secara mandiri perlakuan teknik sterilisasi yang berbeda berpengaruh nyata terhadap panjang akar sorgum (Tabel 3). Perlakuan sterilisasi menggunakan autoklaf dan kontrol menghasilkan panjang akar masing-masing sebanyak 15,47 (meter per tanaman) dan 15,45 (meter per tanaman) tidak berbeda nyata dengan sterilisasi menggunakan iradiasi gamma Co-60 menghasilkan panjang akar 18,43 (meter per tanaman), namun berbeda nyata dengan perlakuan sterilisasi $\mathrm{NaOCl} 10 \%$ menghasilkan panjang akar 9,26 (meter per tanaman).

Tabel 3. Pengaruh Jenis Sterilisasi dan Komposisi Media terhadap Panjang Akar Sorgum pada 10 MST

\begin{tabular}{lr}
\hline \multicolumn{1}{c}{ Perlakuan } & Panjang Akar \\
\hline & $\begin{array}{r}--\mathrm{m} \text { per } \\
\text { tanaman-- }\end{array}$ \\
\hline $\begin{array}{c}\text { Sterilisasi (S) } \\
\text { kontrol }\end{array}$ & 15,47 b \\
autoklaf & 15,45 b \\
NaOCl 10\% & 9,26 a \\
Iradiasi Gamma Co-60 & 18,43 b \\
\hline Komposisi Media (K) & 14,03 a \\
zeolit 100 \% & 15,17 a \\
zeolit 75 \% + arang sekam 25 \% & 14,76 a \\
zeolit 50 \% + arang sekam 50 \% & \\
\hline Keterangan : Nilai rata-rata yang dikuti huruf yang sama \\
tidak berbeda nyata menurut Uji Lanjut Jarak \\
Berganda Duncan pada taraf 5\%.
\end{tabular}

Seperti halnya bobot akar, perlakuan sterilisasi media dengan pemberian $\mathrm{NaOCl}$ $10 \%$ menghasilkan panjang akar paling rendah. Juniper dan Abbott (2004) menyatakan bahwa adanya toksisitas ion 
seperti $\mathrm{Cl}$ dapat merusak jaringan akar tanaman khususnya dan dapat menghambat pertumbuhan tanaman pada umumnya.

Hasil analisis panjang akar menunjukkan bahwa perlakuan sterilisasi dengan iradiasi gamma Co-60 cenderung lebih tinggi dibandingkan dengan perlakuan sterilisasi media lainnya, sejalan dengan hasil penelitian Nurrobifahmi et al. (2017) bahwa sterilisasi iradiasi gamma mampu mematikan mikroba lebih tinggi. Hal ini dapat menyebabkan kemampuan FMA dalam mengkolonisasi akar inangnya menjadi lebih tinggi, yang pada akhirnya berpengaruh terhadap peningkatan panjang akar tanaman inang mikoriza. Kemampuan FMA dalam mengkolonisasi akar yang rendah dapat menyebabkan penyerapan hara yang rendah, sehingga akan berpengaruh terhadap pertumbuhan tanaman sorgum.

\section{SIMPULAN}

Berdasarkan hasil penelitian dapat disimpulkan bahwa teknik sterilisasi berpengaruh terhadap peningkatan kolonisasi akar, panjang akar, dan bobot akar sorgum. Jenis sterilisasi media menggunakan $\mathrm{NaOCl}$ selalu menghasilkan nilai terendah pada semua parameter yang diamati. Metode sterilisasi dengan penggunaan air kran (kontrol) tidak berbeda nyata dengan autoklaf dan Iradiasi Gamma Co-60 dalam meningkatkan kolonisasi akar, panjang akar dan bobot akar sorgum. Perlakuan komposisi media zeolit dan arang sekam secara umum tidak memberikan perbedaan yang nyata, sehingga produksi inokulan FMA dapat menggunakan berbagai komposisi sesuai dengan ketersediaan bahannya.

\section{DAFTAR PUSTAKA}

Bertham, YH. 2003. Teknik Pemurnian Biakan Monoxonic CMA dengan Metode Cawan Petri dan Tabung Reaksi. Jurnal IImu-ilmu Pertanian Indonesia. 5:18-26.

Brundrett, MN, B. Bougher, TG Dell and N. Malayczuk. 1996. Working with Mycorrhizas in Forestry and Agriculture. ACIAR Monograph 32. Australian Centre for International Agricultural Research, Canberra.

Departemen Pertanian. 1990. Teknologi Budidaya Sorgum. Balai Informasi Pertanian Provinsi Irian Jaya, Jayapura.

Departemen Pertanian. 2001. Zeolit untuk Pertanian. Lembar Informasi Pertanian No. 15 Seri : Tanaman Pangan/2001/djs Agdex : 530. Jawa Barat, Bandung.

Gunawan, AW. 1999. Teknik Pembuatan Kultur Cendawan Mikoriza Arbuskula. Makalah Workshop Mikoriza "Aplikasi Cendawan Mikoriza pada Tanaman Pertanian, Perkebunan dan Kehutanan". Asosiasi Mikoriza Indonesia, Bogor.

Ijdo, M., Cranenbrouck, S., and Declerck, S. 2010. Methods for Large-Scale Production of AM Fungi Past, Present, and Future. Mycorriza. DOI 10.1007/s00572-010-0337-z.

Juniper, S., and L. Abbott. 1993. VesicularArbuscular Mycorrhizas and Soil Salinity. Mycorrhiza 4:45-57.

2004. A change in the concentration of $\mathrm{NaCl}$ in soil alters the rate of hyphal extension of some arbuscular mycorrhizal fungi. Canadian J. Botany 82:1235-1242.

Nurbaity, A., D. Herdiyantoro, dan O. Mulyani. 2009. Pemanfaatan Jerami dan Arang Sekam Sebagai Bahan Pembawa Inokulan Mikoriza Arbuskula. Jurnal Biologi Vol. XIII No.1. 
Nurrobifahmi, I. Anas, Y. Setiadi, Ishak. 2017. Pengaruh Metode Sterilisasi Iradiasi Sinar Gamma Co60 terhadap Bahan Pembawa dan Viabilitas Spora Gigaspora margarita. Jurnal Tanah dan Iklim (Indonesian Soil and Climate Journal), Vol 41, No 1.

Prafithriasari, M. dan A. Nurbaity. 2010. Media Zeolit-Arang Sekam dan Pengaruhnya terhadap Pertumbuhan Sorgum. Jurnal Agrikultura Vol 1 no. 1.

Prematuri, R dan N. Faiqoh. 1999. Produksi Inokulum Cendawan Mikoriza Arbuskula. Bogor: Laboratorium Bioteknologi Hutan, PAU Bioteknologi IPB, Bogor.

Rao, NS. 1994. Mikroorganisme Tanah dan Pertumbuhan Tanaman. Terjemahan $\mathrm{H}$. Susilo. Universitas Indonesia Press, Jakarta.

Santoso, U dan Nursandi, F. 2003. Kultur Jaringan Tanaman. Universitas Muhammadiyah Malang, Malang.
Simanungkalit, RDM. 2003. Teknologi Cendawan Mikoriza Arbuskuler : Produksi Inokulan dan Pengawasan Mutunya. Makalah Seminar Mikoriza. AMI, Bandung. 16 September 2003. 2006. Cendawan Mikoriza Arbuskula. Balai Besar Penelitian dan Pengembangan Sumberdaya Lahan dan Pertanian. Bogor. ISBN 978-979-9474-575. 159-190.

Smith, SE, and DJ, Read. 1997. Mycorrhizal symbiosis. Academic Press. London.

St. John, TV, DC Coleman and CPP Reid. 1983. Association of Vesicular Arbuscular Mycorrhizal Hyphae with Soil Organic Particles. Ecology. 64: 957-959.

Tian, CY, Feng G, Li XL, and. Zhang, FS. 2004. Different Effects of Arbuscular Mycorrhizal Fungal Isolates from Saline or Non-Saline Soil on Salinity Tolerance of Plants. Applied Soil Ecology 26:143148. 